\title{
The Free Flap Based on a Single Proximal Perforator of Radial Artery: the Ultrasonography Study and Clinical Applications in Reconstruction of Digital Defect
}

\section{Guangzhi Wu}

China-Japan Union Hospital of Jilin University

\section{Zhan Zhang}

China-Japan Union Hospital of Jilin University

\section{Fan Zhang}

China-Japan Union Hospital of Jilin University

\section{Yiqun Zhang}

China-Japan Union Hospital of Jilin University

Wei Yu ( $\nabla$ yuweiwei@jlu.edu.cn )

China-Japan Union Hospital of Jilin University

\section{Research}

Keywords: Free Radial Artery Perforator Flap, Digital soft tissue defects

Posted Date: June 22nd, 2020

DOl: https://doi.org/10.21203/rs.3.rs-36958/v1

License: (c) (1) This work is licensed under a Creative Commons Attribution 4.0 International License. Read Full License 


\section{Abstract}

Objectives: To locate the anastomosable constant perforator of radial artery on the proximal forarm using ultrasonography, and describe the application of free radial artery flap based on a single proximal perforator in the reconstruction of digital soft tissue defects.

Methods: In 20 forarms (10 right and 10 left) from 10 volunteers, the perforators in the proximal half of forarm from radial artery were visualized by ultrasonography. Then the free radial artery perforator flaps based on the single perforator were used for reconstruction of small digital soft tissue defects in 4 cases between October 2017 and May 2018.

Results: Of the 20 forarms, anastomosable perforator was constantly detected from the radial artery in the proximal half of forarm. The diameter of the perforator was $0.7 \pm 0.1 \mathrm{~mm}$, the pedicle length is $12 \pm 3 \mathrm{~mm}$ by ultrasonography. Ther location of the perforator is far from elbow crease $8.8 \pm 1.4 \mathrm{~cm}$, and the relative distance of the perforator location from elbow crease to wrist crease is $37.2 \% \pm 4.8 \%$. In clinical cases, all the flaps were complete survival. Flap size ranged from 3.5 to $6.5 \mathrm{~cm}$ in length and 2.3 to $3.0 \mathrm{~cm}$ in width. Donor sites of forearm were closed primarily in all cases. During a mean period of 12 months (8-14 months) follow-up, the mean Brief Michigan Hand Questionnaire (BMHQ) score was 72.9 (60.4-85.4) in the affected hand.

Conclusions: There is an anastomosable perforator consistent located on the radial artery in the proximal half of forarm. The free radial artery small flap based on this single perforator provides acceptable functional and cosmetic outcomes for the reconsturction of digital soft tissue defects. With the preservation of the main vessel (radial artery) of forearm, this flap provides another reliable option for handsurgery surgeon to reconstruct small digital defects.

\section{Introduction}

There are many options for reconstruction of soft tissue defects in the fingers, such as traditional or regional pedicled flaps and free flaps, while the reconstruction of small digital defects (especially multiple digital defects) still presents a challenge to the hand surgeon. Due to the obvious limitations of pedicled flaps: Bulk, colour, texture mismatch, donor morbidity, free flaps have been recognized as the best reconstructive option of small digital defects. ${ }^{[1-3]}$ Various small free flaps can be harvested from thenar, forearm (including arterialised venous flap), groin, partial toe and plantar of foot to reconstruct small digital defects in clinic, ${ }^{[4-9]}$ while there is not golden donor site for digital defects reconstruction using the small free flap.

Since the radial forearm flap has been first descripted by Yang in $1978^{[10]}$, the anatomy of perforators of radial artery in forearm have been studied systematically ${ }^{[11-12]}$, and this perforator cluster pedicle flap has been widely used in head or neck reconstruction as a free transer, ${ }^{[13]}$ and hand or elbow soft defects reconstruction as a reginal transer. ${ }^{[14-15]}$ Howerer, either free or pedicle radial forearm flap which is havested as traditional surgical technique has the main limitations is that the flap must sacrifice a major 
axial artery for upper extremity. In 2004 and 2005,in order to preserve of the radial artery, Lin and Omer firstly attempted to havest proximal perforator clusters flap from radial artery of forearm to reconstruct

head and hand defects,respectively. ${ }^{[16-17]}$ Duplex ultrasonography is a well-known method of identifing and evaluating the perforators for free flap transfer. The aim of this study is to locate a constant anastomosable perforator of radial artery on the proximal forarm using ultrasonography, and then raise a free flap based on this single perforator in clinical cases to assess the flap's potential application for reconstruction of the digital soft tissue defect.

\section{Materials And Methods}

\section{Ultrasonography Study}

In 20 forarms (10 right and 10 left) from 10 healthy volunteers ( 5 women and 5 men) with a mean age of 32 years old (range from 23 to 49 years old), the perforators arising from the radial artery were identified in the proximal half of forarm by Dopple ultrasonography (Siemens, Acuson s2000; siemens medical solutions USA, inc; CA, USA). All of the 10 volunteers were right handed and had no medical history of upper limb trauma, surgery, peripheral vascular disorders, or systemic metabolic diseases. When the radial artery and its perforator were identified and located with a $14 \mathrm{~L} 5$ high-frequency probe $(5-14 \mathrm{MHz})$ under the position of forearm completely supinated, the perforator internal diameter and the pedicle length from radial artery to deep fascia were measured and recorded.(Fig. 1) The distance from the perforator location to the elbow crease $\left(D_{p}\right)$ and the distance from the elbow crease to the wrist crease $\left(D_{E-W}\right)$ were measured, then relative distance of the perforator location on the ratio from the elbow crease to the wrist crease was calculated $\left(D_{\mathrm{p}} / \mathrm{D}_{\mathrm{E}-\mathrm{W}} \times 100 \%\right)$.(Fig. 2) All the data were recorded as mean \pm standard deviation.

\section{Patients}

Between Oct 2017 and May 2018, 4 patients (1 men and 3 women) underwent reconstruction of digital soft tissue defects using the free radial artery perforator flaps based on the single perforator under the China-Japan Union Hospital of Jilin University ethics committee-approved protocol. The ages of the patients ranged from 21 to 47 years. 3 of 4 patients had double or multiple digital defects, the free radial artery perforator flap was used to reconstruct one digital soft tissue defect, other digital soft tissue defects were reconstructed by orther free flaps (such as superficial palmar branch of radial artery free flap or dorsal interosseous artery free flap).

\section{Surgical Technique}

Before the operation, the location of the perforator arising from the radial artery was determined and marked in the proximal half of forarm by ultrasonography. Under general anaesthesia or brachial plexus block anaesthesia, the patient was placed in a supine position, with the upper extremity 90 degrees abduction resting on a well-padded arm board. The operation was performed under pneumatic tourniquet control without limb exsanguination and under microscopic magnification to permit better identification of the perforator vessels. After the devitalised tissue in the wound was debrided, the recipient vessels were 
prepared in the defect. Depending on the size, shape of the resulting defect, a free flap was drawn on the proximal forarm. The center of the flap was designed at the location of perforator entering into deep fascia, which was marked by ultrasonography pre-operatively. The axis of the designed flap was the line from the middle point of cubital fossa to the pulsation point of radial artery at styloid process. The flap elevation was started from the lateral border until the perforator vessel originating from the radial artery was detemined between the brachioradialis and the pronator teres muscles. Then the medial border of the flap was incised and retrograde dissection of the single perforator was conducted to the fascia where the pedicle arose. Another one subcutaneous vein should be preserved and havested into the designed flap to guarantee the venous return of the flap, and the branch of lateral antebrachial cutaneous nerve should be havested into the flap and anastomosed to a cutaneous sensorial nerve of the recipient site if possible. Then the flap was completely elevated from the deep fascia. After releasing the tourniquet, the perfusion of flap was confirmed, the perforator pedicle can be divided at its origin from the radial artery and vena comitantes. The presevative subcutaneous vein was also divided according to desired length of recipient vein. The raised flap was placed on the digital defect, and the vessles of flap pedicle was anastomosed in an end-to-end fashion to the recipient vessles using 11-0 Prolene suture (Ethicon, USA) under the microscope. The flap margin was sutured to the defect margin, and the donor site of flap was closed primarily.

\section{Postoperative Management and Follow-up}

Standard postoperative free flap care and monitoring was performed for 7 days. Routine wound cleansing was accomplished using iodophor postoperation. Low molecular weight heparin (5000 IU per day) and lower molecular weight dextran (500 mL per day) were continuous used to prevent thrombosis of the microsurgical anastomoses. All the patients were instructed to avoid strenuous exercise for 3 weeks. All skin sutures were removed at 2 weeks after the operation.

During a period of 12 months follow up, the Brief Michigan Hand Questionnaire (BMHQ) was used for evaluating the flap and the hand function in all the patients. The BMHQ contains 12 questions with a original score of 1 (poor) to 5 (ideal) regarding 6 domains of the hand function (overall function, daily life activities, work performance, pain, aesthetics and satisfaction), and then the original scores were finally calculated on a scale from 0 (poorest function) to 100 (ideal function) using the formula: 100×(BMHQ raw score-1)/4. Higher scores indicate better functioning and satisfaction. ${ }^{[18]}$

\section{Results}

\section{Ultrasonography Result}

The anastomosable perforator is constantly detected from the radial artery in the proximal half of 20 forarms from 10 healthy volunteers by ultrasonography. The internal diameter of the perforator is $0.7 \pm 0.1$ $\mathrm{mm}$; the pedicle length from radial artery to deep fascia is $12 \pm 3 \mathrm{~mm}$; the distance from the perforator location to the elbow crease $\left(D_{p}\right)$ is $8.8 \pm 1.4 \mathrm{~cm}$, and the relative distance of the perforator location 
beyongd the elbow crease $\left(D_{p} / D_{E-W} \times 100 \%\right)$ is $37.2 \% \pm 4.8 \%$ ( Elbow crease is $0 \%$; wrist crease is $\left.100 \%\right)$. ( Tab. 1)

\section{Clinical Result}

The cases of flap were shown in Fig. 3-5. All the flaps were harvested from the ipsilateral forearm, and the donor sites were closed directly. The size of the flaps ranged from $3.5-6.5 \mathrm{~cm}$ to $2.3-3.0 \mathrm{~cm}$. The diameter of the single perforator was $0.5-0.7 \mathrm{~mm}$. There were no early complications (eg, infection, wound dehiscence, hematoma, and vascular congestion) in the cases and all the flaps were survival completely. During the follow-up period, no patient experienced cold intolerance, abnormal sensory, scar pain. There were no functional impairments and at the donor sites. The data of patients and outcomes were shown in Tab. 2. The average follow-up time was 12 months (range 8-14 months). The mean BMHQ total score in all the patients was 72.9 (range 60.4-85.4), including the overall hand function score was 78.1 (range 62.587.5), the activities of daily living score score was 78.1 (range 62.5-100), the work performance score was 62.5 (range 50-75), pain score was 62.5 (range 50-75), aesthetics score was 68.8 (50-87.5), selfsatisfaction score was 87.5 (range 75-100). The functional outcomes estimated by BMHQ of all the patients were show in Tab. 3.

\section{Discussion}

Various trauma often leaves the hand surgeon with a complex defect in the hand, and the small defect (especially multiple digital defects) is always challenging for reconstruction. The ideal reconstruction of digital defects is the preservation function of hand as much as possible, meanwhile, providing an aesthetic appearance both in recipient and donor region. So among the various options for reconstruction of small soft tissue defects in the fingers, the free flaps have been recognized as the best reconstructive option. $\cdot^{[1-3]}$

The radial forearm flap has been first descripted by Yang in 1978, ${ }^{[10]}$ and this pedicle flap has been established its role in plastic reconstructive field by surgeons. ${ }^{[13-15]}$ Howerer, either free or pedicle radial forearm flap remains the main disadvantage is that the sacrifice of a major artery to the upper extremity. Generally, sacrifice of the radial artery doesn't cause an ischemic problem unless the ulnar artery has been previously injuried in the upper extremity. However, several studies have reported serious complication (eg.

hypothenar hammer syndrome; dry gangrene of fingers) after harvesting a radial forearm flap. ${ }^{[19-20]}$ Based on the the anatomical study of proximal perforators of radial artery in forearm, ${ }^{[11-12]}$ Lin and Omer attempted preliminarily to havest this perforator free flap in order to preserve of the radial artery in clinic, [16-17] and then there are few literature to describe and use the proximal perforator from radial artery of forearm for free tansfer. We design this study is to locate a constant anastomosable perforator of radial artery on the proximal forarm using ultrasonography, and then raise a free flap based on this single perforator in clinical cases to assess the flap's potential application for reconstruction of the digital soft tissue defect. 
Several previous studies about the perforators analysis of radial artery have confirmed that two main clusters perforators ( $\geq 0.5 \mathrm{~mm}$ diameter; distal cluster and proximal cluster) in forarm could be potentionally used for flap transfer in clinic. ${ }^{[11,14]}$ Michel et al. have futher detamined that the proximal cluster perforators of radial artery located at a distance of 61.7 percent along the radial styloid-to-lateral epicondyle interval in an anatomical cadaver study. The perforators reveal no statistical difference in either radial or ulnar distribution originated from the radial artery. In our study, an anastomosable perforator originated from the radial artery can be always detected in all volunteers' proximal forarm. This perforator location at about $8.8 \mathrm{~cm}$ far from the elbow crease, and the relative distance is about $37.2 \%$ along the elbow crease to wrist crease interval, which is consistent with the previous study. Furthermore, this perforator is an intermuscular septal type coursing between the brachioradialis and the pronator teres muscles, and the pedicle length is $12 \mathrm{~mm}$, the internal diameter is $0.7 \mathrm{~mm}$ under ultrasonography. These ultrasonography data illustrate the perforator is consistently located at the radial artery in the proximal half of forarm, and designing a free flap based on this single perforator could be achieved. Furthermore, the diameter of the perforator can match with digit artery well in the reconstruction of finger. The multiple superficial veins in forarm can be harvested as an alternative donor vein for venous drainage. Our study is also proved the importance of ultrasonography preoperatively. Ultrasonography is an simple and noninvasive inspection method to locate an small perforaor for desiging a flap. So we suggest the perforator inspection and location using ultrasonography should be an routine examination before a flap operation.

How much aera could the free flap based on a single perforator of radial artery be done? According the anatomical study about proximal perforators of radial artery, several perforators coming off the radial artery travel to the skin and form linking networks with each other along the radial arter as axis (about $2 \mathrm{~cm}$ wide). ${ }^{[11]}$ This network of vessels between the fascia and the dermis ensure the adequate blood supply for designing a long free flap $\left(10 \mathrm{~cm}-18 \mathrm{~cm}\right.$ reported by Lin JY $\left.{ }^{[16]}\right)$, meanwhile, the wide of free flap is limited (usually $\leq 4 \mathrm{~cm}$ ). This shape feature of an oblong flap is especially suit to reconstruct the defect in long finger. There are some other more advantages of the radial artery proximal perforator free flap: fitstly, the single perforator flap haversting preserves the radial artery avoiding the potentional ischemic problem of upper extremity; secondly, the flap can provide the similar colour and texture match and aesthetic apperance of the finger; thirdly, the lateral antebrachial cutaneous nerve can be havested into the flap to recovery excellent sensory of finger; lastly, the operation can be one stage performed in a single operative field.

Brief Michigan Hand Questionnaire (BMHQ) is the brief version of MHQ established in 2011, which including six distinct domains (Overall function, Daily life activities (ADL), Work performance, Pain, Aesthetics and Satisfaction). Every patient needs to answer 2 questions in each domain (a total of 12 questions), each question is assigned a score from 1 (min=poorest) to 5 (max=ideal) regarding hand function evaluated by the patient, and then the average original score in each domain is calculated to generate a score that is scaled from 0 (poorest) to 100 (ideal). BMHQ has been demonstrated as a reliable and valid hand specific instrument for evaluating hand function. ${ }^{[18]}$ In this study, the average total score of $\mathrm{BMHQ}$ in four patients is 72.9 (range 60.4 - 85.4), among of which the average satisfaction score is 87.5 , 
the the overall function and ADL scores are 78.1. Thees data indicate that the hand function fully meets the needs of daily life for patients, and the patients are satisfaction with the hand function after the flap surgery. The work performance score and the pain score are both 62.5 , that may attribute the compound tissue damage (including fracture, tendon injury, nerve injury) to limit the functional recovery of the affected hand.

There are also some disadvantages of the radial artery proximal perforator free flap, including: nonconcealed enough morbidity in donor site, bulkiness of the flap in the reconstructive finger, dissection and anastomosis of microvessels. The main morbidity in donor site is the presence of a longitudinal scar in the forarm, so the aesthetics scores self-evaluated by the patients in our study are lower than 70. Due to the small diameter of perforator $(0.7 \mathrm{~mm})$, meticulous dissection is required for flap elevation, and anastomosis requires supermicrosurgical skills.

There are several limitations in this report. First, we could not perform objective examination for precise marking the perforator directly and evaluating blood supply area of a single perforator. Second, the population sample is not large enough in ultrasonography study, and the clinical implications of radial artery proximal perforator free flap are limited.

\section{Conclusions}

There is an anastomosable perforator consistent located on the radial artery in the proximal half of forarm. Preoperative detection and locating this perforator using ultrasonography can facilitate elevation of the flap. With the consistent anatomy of perforator and the satisfactory outcome in clinic application, the free radial artery small flap based on a single perforator (preservation radial artery) is a reliable and useful option for reconstruction of digital defect.

\section{Declarations}

\section{Ethical Approval and Consent to participate}

Not applicable

\section{Consent for publication}

All authors have read and approved the final manuscript and declare that they have no competing interests.

\section{Availability of data and materials}

The datasets used during the current study are available from the corresponding author upon reasonable request.

\section{Competing interests}


None of the authors has any conflict of interest to disclose.

\section{Funding}

Jilin Province Science and Technology Development Project (No.20190201244JC).

\section{Authors' contributions}

Wu Guangzhi and Zhangzhan responsible for surgery in clinic study and have equal contribution. Zhang Fan completed the ultrasound study and examination of the patient. Zhang Yiqun analyzed the data and completed patient follow-up. Yu Wei contributed to the study design, data analysis, reviewed the manuscript. All authors read and approved the final manuscript.

\section{Acknowledgements}

We thank all funding agencies for supporting this study

\section{References}

1. Liu Y, Jiao H, Ji X, et al. A Comparative Study of Four Types of Free Flaps from the Ipsilateral Extremity for Finger Reconstruction[J]. PLOS ONE, 2014, 9.

2. Diaz-Abele J, Hayakawa T, Buchel E, et al. Anastomosis to the common and proper digital vessels in free flap soft tissue reconstruction of the hand[J]. Microsurgery, 2016.

3. Narushima M, lida T, Kaji N, et al. Superficial circumflex iliac artery pure skin perforator-based superthin flap for hand and finger reconstruction [J]. Journal of Plastic Reconstructive Aesthetic Surgery. 2016;69(6):827-34.

4. Noh SM, Kim JS, Lee DC, et al. Reconstruction of Soft Tissue Defect of the Finger with Thenar Free Flap[J]. 2008.

5. Tancharoen C, Niumsawatt V, Ek EW, et al. Free distal volar forearm perforator flap: clinical application in digital reconstruction[J]. Anz Journal of Surgery. 2014;84(6):459-63.

6. Wharton R, Creasy H, Bain C, et al. Venous flaps for coverage of traumatic soft tissue defects of the hand: a systematic review[J]. J Hand Surg Eur Vol. 2017;42(8):817-22.

7. Tare M, Ramakrishnan V. Free 'mini' groin flap for digital resurfacing. J Hand Surg Eur Vol. 2009;34:336-42.

8. Orbay JL, Rosen JG, Khouri RK, Indriago I. The glabrous palmar flap: the new free or reversed pedicled palmar fasciocutaneous flap for volar hand reconstruction. Tech Hand Up Extrem Surg. 2009;13:14550.

9. Koshima I, Urushibara K, Inagawa K, Hamasaki T, Moriguchi T. Free medial plantar perforator flaps for the resurfacing of finger and foot defects. Plastic Reconstr Surg. 2001;107:1753-8.

10. Yang G, Yuzhi G. Forearm free skin flap transplantation. Natl Med J China. 1978;61:139. 
11. Saint-Cyr M, Mujadzic M, Wong C, et al. The Radial Artery Pedicle Perforator Flap: Vascular Analysis and Clinical Implications[J]. Plast Reconstr Surg. 2010;125(5):1469-78.

12. Onode E, Takamatsu K, Shintani K, et al. Anatomical Origins of Radial Artery Perforators Evaluated Using Color Doppler Ultrasonography[J]. J Reconstr Microsurg. 2016;32(08):594-8.

13. Tornero AOJ, Cruztoro AOP, Articles of Anna Farré, et al. Free radial forearm flap in head and neck: our experience].[J]. Acta Otorrinolaringol Esp, 2014, 65(1):27-32.

14. Tiengo $C$, Macchi V, Porzionato A, et al. The proximal radial artery perforator flap (PRAP-flap): An anatomical study for its use in elbow reconstruction. Surg Radiol Anat. 2007;29:245-51.

15. Koshima I, Narushima M, Mihara M. The Radial Artery Perforator-Based Adipofascial Flap for Coverage of the Dorsal Hand[J]. Color Atlas of Burn Reconstructive Surgery, 2010(5):428-433.

16. Lin JY, Cheng MH, Wei FC, et al. Proximal Forearm Flap Based on a Septocutaneous Vessel from the Radial Artery[J]. Plast Reconstr Surg. 2006;117(3):955-60.

17. Ozkan O, Akyürek M, Coşkunfirat OK, et al. The Free Radial Artery Septal Perforator Vessel-Based Flap[J]. Plast Reconstr Surg. 2005;115(7):2062-9.

18. Waljee JF, Kim HM, Burns PB, Chung KC. Development of a Brief, 12-Item Version of the Michigan Hand Questionnaire[J]. Plast Reconstr Surg. 2011;128:208-20.

19. Jones $B M, O$ 'Brien $C J$. Acute ischemia of the hand resulting from elevation of a radial forearm flap. $\mathrm{Br}$ J PlastSurg. 1985;38:396.

20. Heller F, Wei W, Wei FC. Chronic arterial insufficiency of the hand with finger tip necrosis 1 year after harvesting a radial forearm free flap. Plast Reconstr Surg. 2004;114:728.

\section{Tables}

Table 1. The location and ultrasonography findings of the radial artery perforator in the proximal forarm. $\bigotimes n=20 \bigotimes$ 


\begin{tabular}{|c|c|c|c|c|c|c|c|}
\hline No. & Sex & Age & Side & $\begin{array}{l}\text { Diameter } \\
(\mathrm{mm})\end{array}$ & $\begin{array}{l}\text { Pedicle Length } \\
(\mathrm{mm})\end{array}$ & $\begin{array}{l}\mathrm{D}_{\mathrm{p}} / \mathrm{D}_{\mathrm{E}-\mathrm{W}} \\
(\mathrm{cm})\end{array}$ & $\begin{array}{l}\text { Perforator } \\
\text { Location }\end{array}$ \\
\hline \multirow[t]{2}{*}{1} & \multirow[t]{2}{*}{ male } & \multirow[t]{2}{*}{36} & $\mathrm{~L}$ & 0.6 & 15 & $7.7 / 23.4$ & $32.9 \%$ \\
\hline & & & $\mathrm{R}$ & 0.7 & 15 & $9.0 / 23.5$ & $38.3 \%$ \\
\hline \multirow[t]{2}{*}{2} & \multirow[t]{2}{*}{ male } & \multirow[t]{2}{*}{28} & L & 0.5 & 15 & $9.3 / 26.4$ & $35.2 \%$ \\
\hline & & & $\mathrm{R}$ & 0.5 & 20 & $10.8 / 25.1$ & $43.0 \%$ \\
\hline \multirow[t]{2}{*}{3} & \multirow[t]{2}{*}{ female } & \multirow[t]{2}{*}{33} & $\mathrm{~L}$ & 0.5 & 14 & $9.8 / 23.4$ & $41.9 \%$ \\
\hline & & & $\mathrm{R}$ & 0.5 & 13 & $6.7 / 23.5$ & $28.5 \%$ \\
\hline \multirow[t]{2}{*}{4} & \multirow[t]{2}{*}{ male } & \multirow[t]{2}{*}{29} & L & 0.5 & 11 & $9.6 / 24.6$ & $39.0 \%$ \\
\hline & & & $\mathrm{R}$ & 0.8 & 14 & $8.5 / 24.4$ & $34.8 \%$ \\
\hline \multirow[t]{2}{*}{5} & \multirow[t]{2}{*}{ female } & \multirow[t]{2}{*}{23} & $\mathrm{~L}$ & 0.8 & 7 & $7.7 / 22.7$ & $33.9 \%$ \\
\hline & & & $\mathrm{R}$ & 0.6 & 14 & $8.6 / 22.8$ & $37.7 \%$ \\
\hline \multirow[t]{2}{*}{6} & \multirow[t]{2}{*}{ female } & \multirow[t]{2}{*}{49} & $\mathrm{~L}$ & 0.6 & 13 & $9.9 / 22.7$ & $43.6 \%$ \\
\hline & & & $\mathrm{R}$ & 0.8 & 10 & $8.3 / 22.7$ & $36.6 \%$ \\
\hline \multirow[t]{2}{*}{7} & \multirow[t]{2}{*}{ male } & \multirow[t]{2}{*}{26} & $\mathrm{~L}$ & 0.8 & 14 & $10.0 / 25.0$ & $40.0 \%$ \\
\hline & & & $\mathrm{R}$ & 0.9 & 15 & $9.3 / 23.9$ & $38.9 \%$ \\
\hline \multirow[t]{2}{*}{8} & \multirow[t]{2}{*}{ female } & \multirow[t]{2}{*}{42} & L & 0.8 & 9 & $9.6 / 24.3$ & $39.5 \%$ \\
\hline & & & $\mathrm{R}$ & 0.8 & 9 & $7.7 / 23.6$ & $32.6 \%$ \\
\hline \multirow[t]{2}{*}{9} & \multirow[t]{2}{*}{ male } & \multirow[t]{2}{*}{24} & L & 0.7 & 11 & $11.1 / 25.0$ & $44.4 \%$ \\
\hline & & & $\mathrm{R}$ & 0.8 & 11 & $9.8 / 24.5$ & $40.0 \%$ \\
\hline \multirow[t]{2}{*}{10} & \multirow[t]{2}{*}{ female } & \multirow[t]{2}{*}{34} & L & 0.7 & 5 & $5.6 / 21.1$ & $26.5 \%$ \\
\hline & & & $\mathrm{R}$ & 0.5 & 10 & $7.4 / 20.8$ & $35.6 \%$ \\
\hline \multicolumn{2}{|c|}{$\operatorname{AVE}(x(-) \pm s)$} & $32 \pm 8$ & - & $0.7 \pm 0.1$ & $12 \pm 3$ & $\begin{array}{l}8.8 \pm 1.4 / \\
23.7 \pm 1.3\end{array}$ & $37.2 \% \pm 4.8 \%$ \\
\hline
\end{tabular}

Diameter: The internal diameter of the perforator vessel of radial artery measured by e ultrasonography .

Pedicle Length: The pedicle distance from its origination of radial artery to deep fascia by ultrasonography.

$D_{p}$ : The distance from location of the perforator to the elbow crease. 
$D_{E-W}$ : The distance fromthe elbow crease to the wrist crease.

Perforator Location $=D_{p} / D_{E-W} \times 100 \%$ : The relative distance of the perforator location beyongd the elbow crease.

Table 2. The data of patients and outcomes of the free radial artery perforator flap.

\begin{tabular}{llllllllll} 
No. Sex & Age & Cause & $\begin{array}{l}\text { Flap } \\
\text { size } \\
\text { (cm) }\end{array}$ & $\begin{array}{l}\text { Perforator } \\
\text { Diameter } \\
\text { (mm) }\end{array}$ & $\begin{array}{l}\text { Recipient } \\
\text { site }\end{array}$ & $\begin{array}{l}\text { Follow- } \\
\text { up time } \\
\text { (month) }\end{array}$ & Complications \\
\hline $\mathbf{1}$ & Female & 21 & $\begin{array}{l}\text { Friction } \\
\text { injury }\end{array}$ & $3.5 \times 3.0$ & 0.6 & $\begin{array}{l}\text { Right } \\
\text { middle } \\
\text { finger }\end{array}$ & 14 & None \\
\hline $\mathbf{2}$ & Female & 47 & $\begin{array}{l}\text { Crush } \\
\text { injury }\end{array}$ & $5.0 \times 3.0$ & 0.6 & $\begin{array}{l}\text { Left } \\
\text { index } \\
\text { finger }\end{array}$ & 12 & None \\
\hline 3 & Female & 45 & $\begin{array}{l}\text { Crush } \\
\text { injury }\end{array}$ & $6.0 \times 2.3$ & 0.5 & $\begin{array}{l}\text { Right } \\
\text { ring } \\
\text { finger }\end{array}$ & 8 & None \\
\hline $\mathbf{4}$ & Male & 39 & $\begin{array}{l}\text { Stamping } \\
\text { injury }\end{array}$ & $6.5 \times 3.0$ & 0.7 & $\begin{array}{l}\text { Right } \\
\text { ring } \\
\text { finger }\end{array}$ & 14 & None \\
\hline
\end{tabular}

Table 3. The functional outcome of the free radial artery perforator flap estimated by BMHQ

No. BMHQ Score

\begin{tabular}{llllllll} 
& $\begin{array}{l}\text { Overall } \\
\text { function }\end{array}$ & ADL & $\begin{array}{l}\text { Work } \\
\text { performance }\end{array}$ & Pain & Aesthetics & Satisfaction & $\begin{array}{l}\text { Total } \\
\text { score }\end{array}$ \\
\hline $\mathbf{1}$ & 87.5 & 87.5 & 75 & 75 & 87.5 & 100 & 85.4 \\
\hline $\mathbf{2}$ & 62.5 & 62.5 & 50 & 50 & 50 & 87.5 & 60.4 \\
\hline $\mathbf{3}$ & 75 & 62.5 & 50 & 50 & 62.5 & 75 & 62.5 \\
\hline $\mathbf{4}$ & 87.5 & 100 & 75 & 75 & 75 & 87.5 & 83.3 \\
\hline $\begin{array}{l}\text { AVE (x(-) } \\
\mathbf{I S})\end{array}$ & $\mathbf{7 8 . 1}$ & $\mathbf{7 8 . 1}$ & $\mathbf{6 2 . 5}$ & $\mathbf{6 2 . 5}$ & $\mathbf{6 8 . 8}$ & $\mathbf{8 7 . 5}$ & $\mathbf{7 2 . 9}$ \\
\hline
\end{tabular}

BMHQ (Brief Michigan Hand Outcomes Questionnaire) includes 12 questions divided into flollowing 6 domains: overall function, daily life activities (ADL), work performance, pain, esthetics and satisfaction. 
The score of every item is normalized on a scale from 0 (poorest function) to 100 (ideal function) as the formula: $100 \times(\mathrm{BMHQ}$ original score-1)/4. The total score is the average of every item.[18]

\section{Figures}

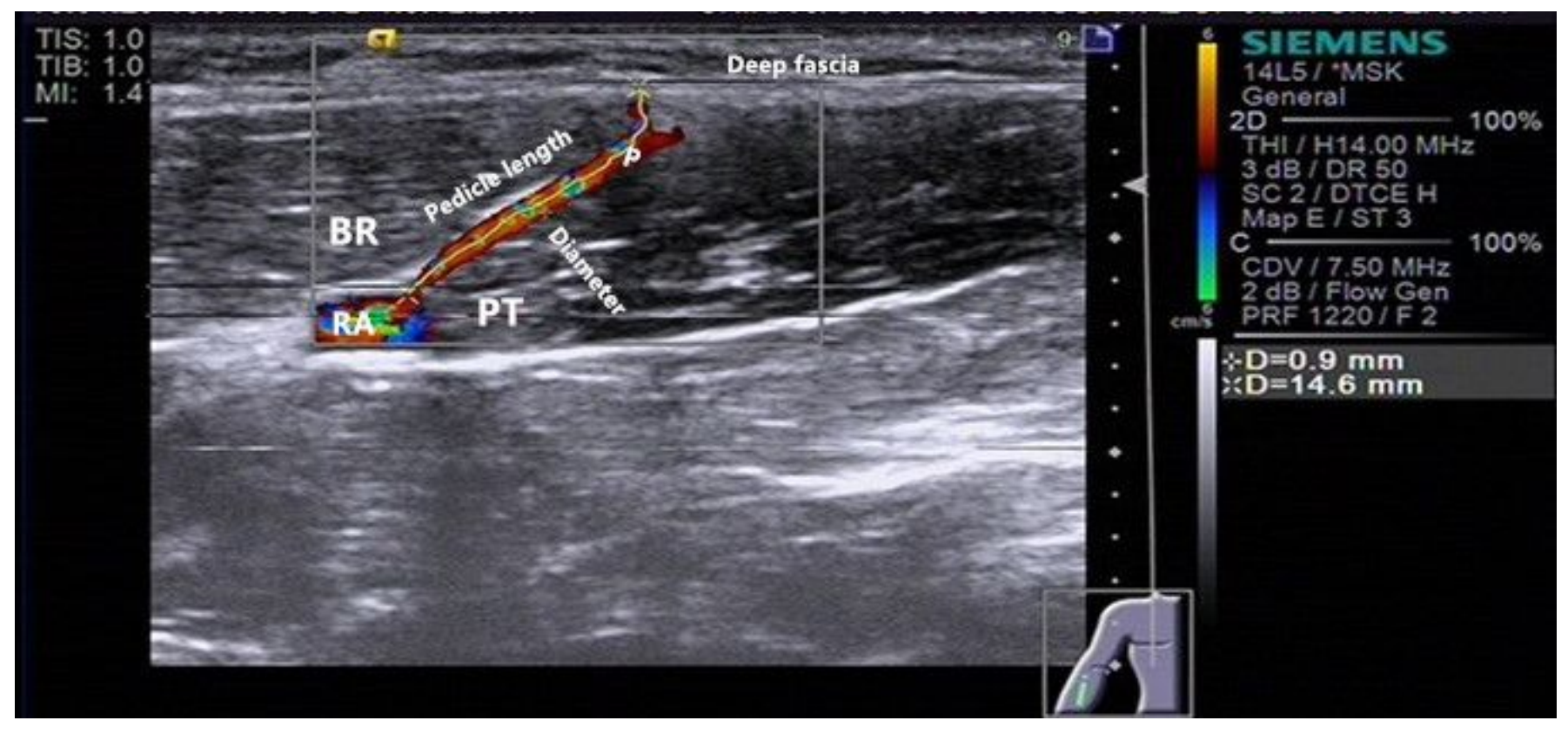

\section{Figure 1}

The perforator of Duplex ultrasound image: a perforator arising from the radial artery between the brachioradialis muscle and pronatorteres muscle in the proximal half of forarm. Diameter(+):The internal diameter of the perforator; Pedicle length $(x)$ : The pedicle distance from its origination of radial artery to deep fascia; RA: radial artery; P:perforator; BR: brachioradialismuscle; PT: pronatorteres muscle. 


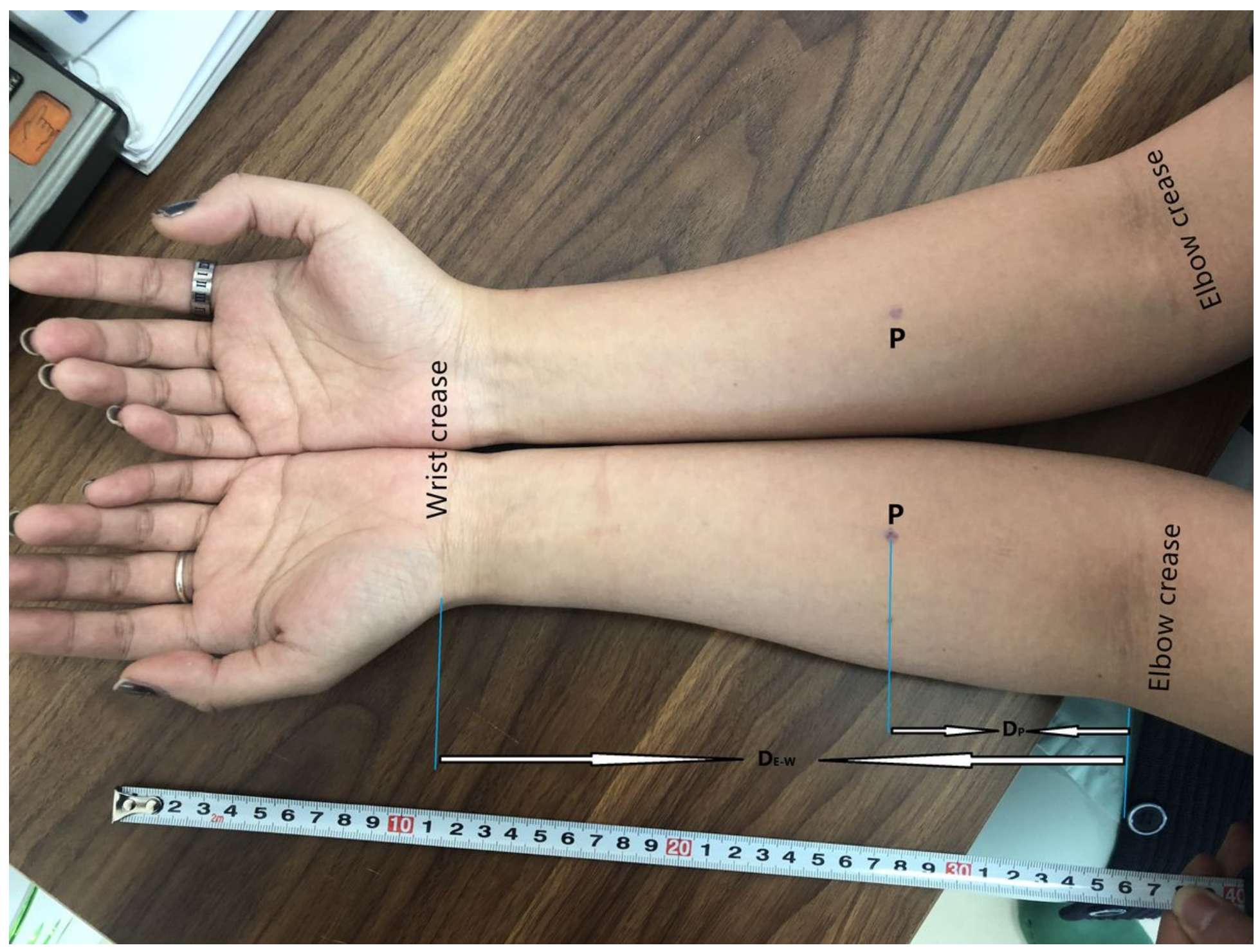

Figure 2

The location of the perforator of the radial artery in the proximal forearm. P:perforator; Dp: The distance from location of the perforator to the elbow crease; DE-W : The distance fromthe elbow crease to the wrist crease. Perforator Location $=\mathrm{Dp} / \mathrm{DE}-\mathrm{W} \times 100 \%$ : The relative distance of the perforator location beyongd the elbow crease. 


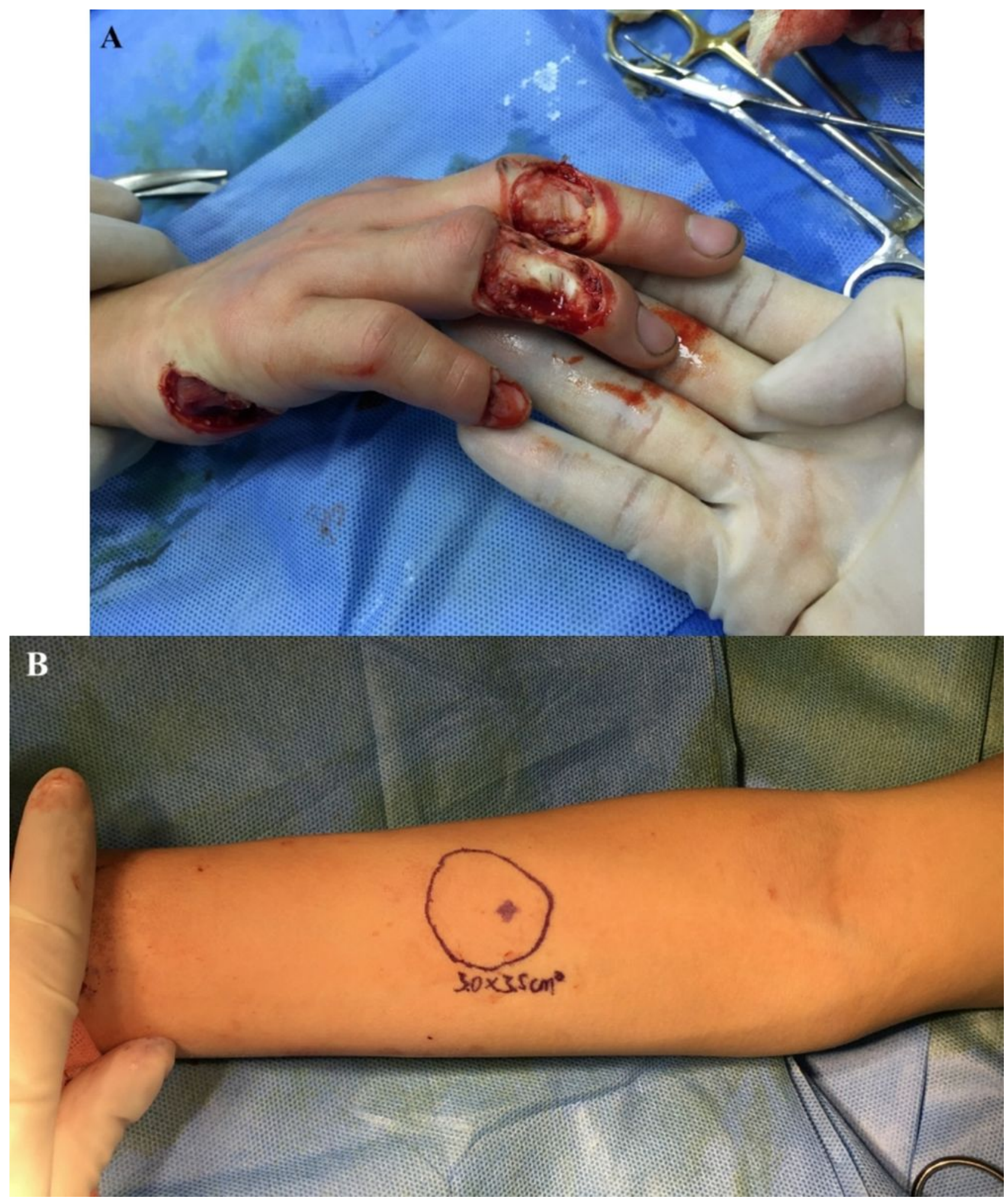

\section{Figure 3}

Case one-friction injury causing the multiple soft tissue defects in middle finger, ring finger and hypothenar area(A). A free radial artery perforator flap was designed(B) to reconstruct the defect in middle finger, basing on the single perforator in the proximal half of forearm(C). The appearance of the flap postoperatively immediately(D) and at 14 months after surgery(E), the functional result(F) and donor site scar(G) were acceptable. (Another free superficial palmar branch of the radial artery flap was designed to 
reconstruct the defect in ring finger; the full-thickness skin graft havesting from forearm.to reconstruct the defect in hypothenar area.)

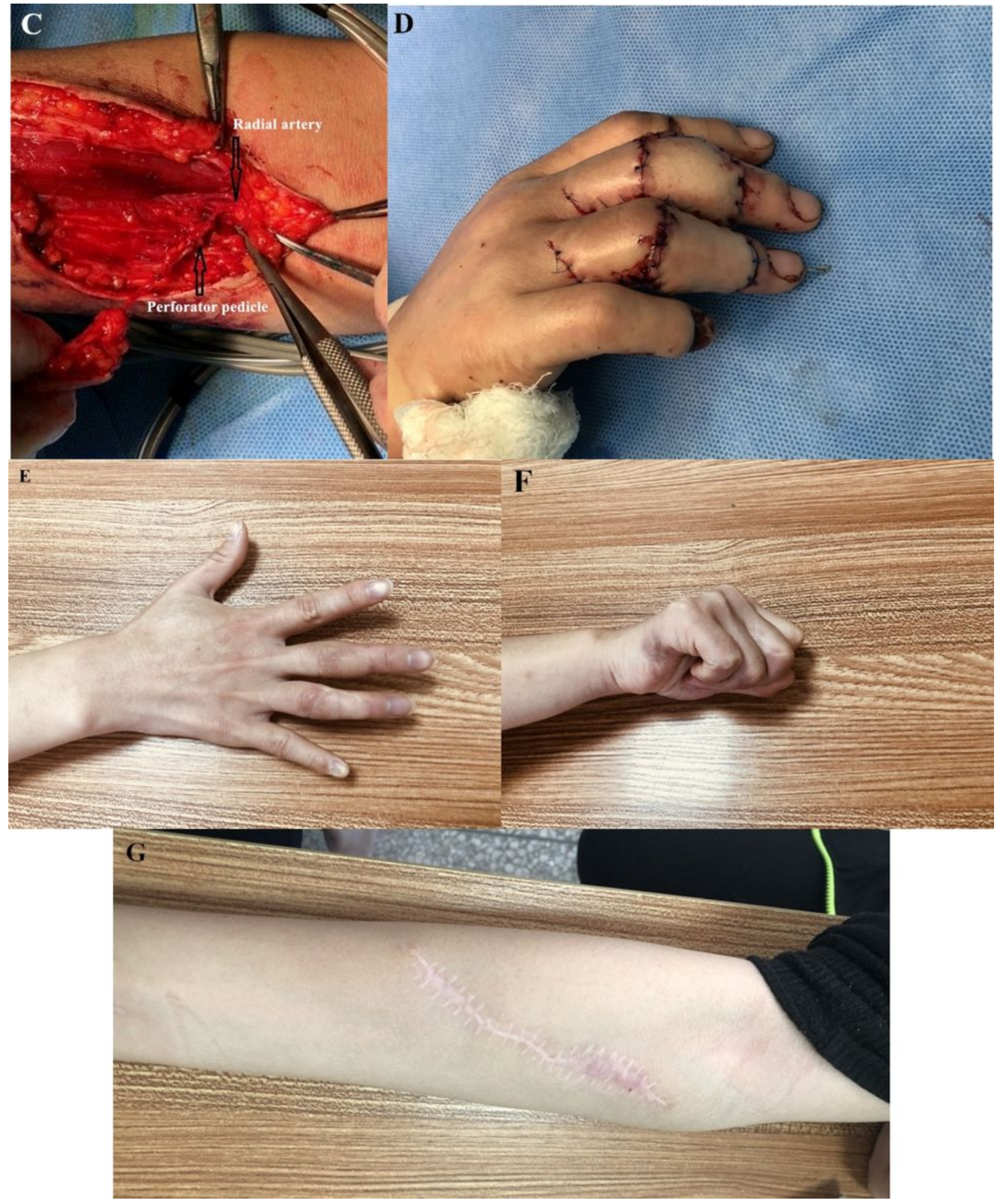

\section{Figure 4}

Case two-crush injury causing the volar soft tissue defects in index finger (A-B). A free radial artery perforator flap was designed, basing on the single perforator in the proximal half of forearm(C). The 
appearance of the flap at 12 months after surgery(D), the functional result (E) and donor site scar(F) were acceptable.

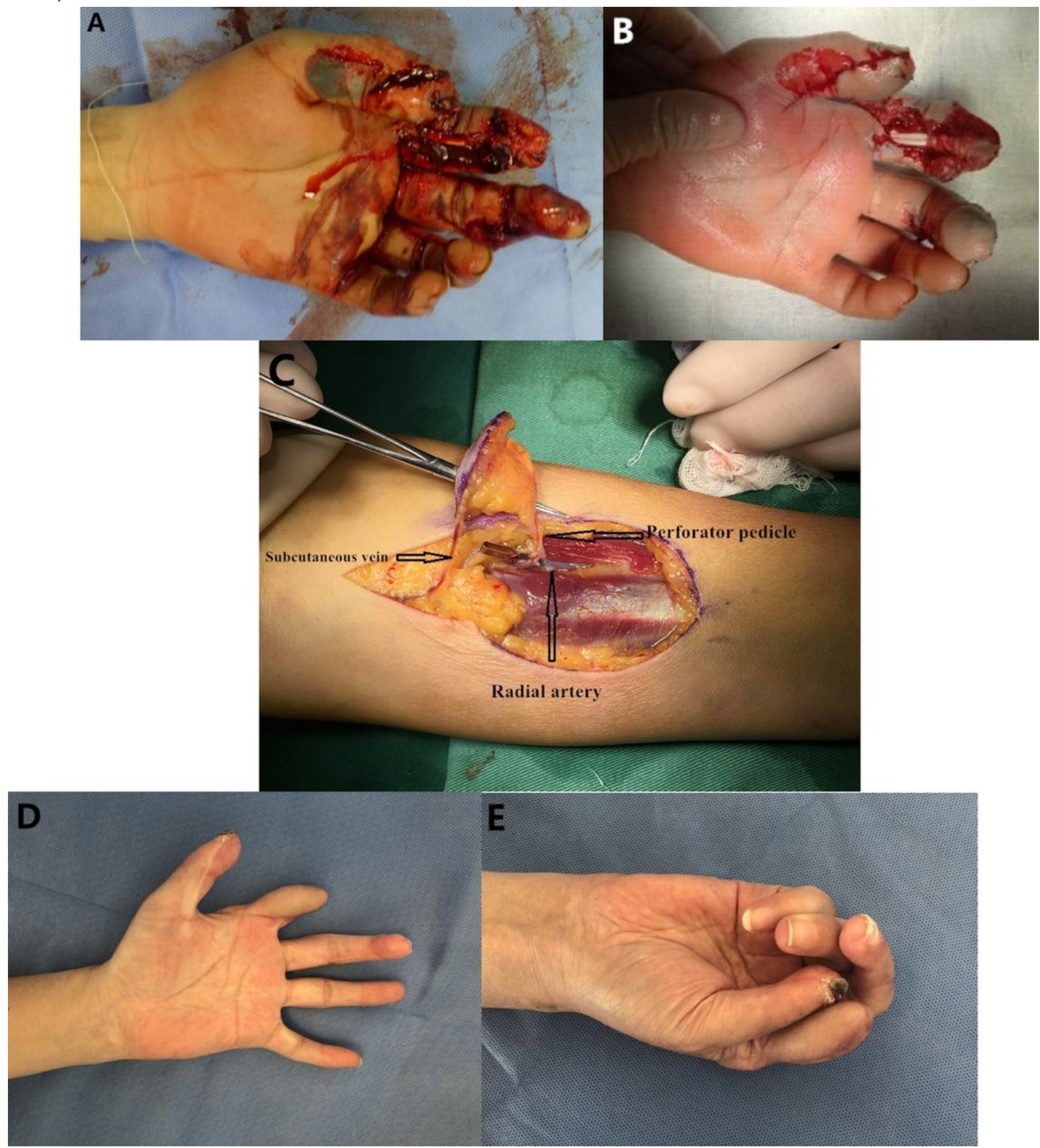

\section{Figure 5}

Case three-crush injury causing the volar soft tissue defects in index finger and ring finger (A). A free radial artery perforator flap was designed(B) to reconstruct the defect in ring finger, basing on the single perforator in the proximal half of forearm(C). The appearance of the flap post-operatively immediately(D) 
and at 8 months after surgery(E), the functional result(F) and donor site scar(E) were acceptable. (An another free superficial palmar branch of the radial artery flap was designed to reconstruct the defect in index finger.) 